University of Minnesota Morris Digital Well

University of Minnesota Morris Digital Well

Winter 2014

\title{
Sarmiento's Vida de Horacio Mann: Translation, Importation, and Entanglement
}

Thomas Genova

University of Minnesota - Morris, tgenova@morris.umn.edu

Follow this and additional works at: https://digitalcommons.morris.umn.edu/span_facpubs

Part of the Latin American Literature Commons

\section{Recommended Citation}

"Sarmiento's Vida de Horacio Mann: Translation, Importation and Entanglement." Hispanic Review, 82.1 (Winter 2014): 21-41.

This Article is brought to you for free and open access by the Faculty and Staff Scholarship at University of Minnesota Morris Digital Well. It has been accepted for inclusion in Spanish Publications by an authorized administrator of University of Minnesota Morris Digital Well. For more information, please contact skulann@morris.umn.edu. 


\title{
SARMIENTO'S VIDA DE HORACIO MANN:
}

\author{
TRANSLATION, IMPORTATION, AND
}

\author{
ENTANGLEMENT
}

\author{
Thomas Genova \\ University of Minnesota, Morris
}

\begin{abstract}
This article focuses on the broad sociopolitical implications of Sarmiento's translations of Northern Hemispheric texts and ideas into the South American context in Las escuelas and the author's correspondence with Mary Mann. Exploring the relationship between the two reformers-both of whom were interested in using education to prepare nonwhites for the duties of citizenship in a broadly defined "South"-in order to examine the entangled history of Argentina during the War of the Triple Alliance and the early Reconstruction-era United States, this article shows how Sarmiento puts his relationship with Mann to creative use in his effort to incorporate Argentina's popular classes into the national project through public education. Ultimately, the relationship between the two writers points to how the interplay between transnational conversations and local histories gives rise to the entanglement of imperialism and neocolonialism in the Americas during the second half of the nineteenth century.
\end{abstract}

In 1847, Argentine writer and statesman Domingo Faustino Sarmiento spent an agreeable weekend in Newport, Massachusetts discussing education with North American pedagogue Horace Mann and his wife Mary, who served as their interpreter. When President Bartolomé Mitre sent Sarmiento back to the United States in 1865, the new Argentine minister in Washington contacted the now-widowed Mary Mann in order to inquire about the possibility of translating her 1865 Life of Horace Mann, a biography of her late husband, into Spanish (Las escuelas 299). The result was Sarmiento's 1867 
Vida de Horacio Mann, a text that has been largely neglected by both Sarmientine and inter-American studies, even as Sarmiento's correspondence with Mary Mann, as well as her translation of his Facundo - an 1845 harangue against the Argentine federalista government-increasingly draw scholarly attention. Yet despite this oversight, the Vida, read in the context of Sarmiento's study Las escuelas in which it appears, points to how the interplay between transnational conversations and local histories gives rise to the entanglement of imperialism and neocolonialism in the Americas during the second half of the nineteenth century.

This article focuses on the broad sociopolitical implications of Sarmiento's "translations"- understood in the etymological sense of "carrying across," or transferal—of Northern Hemispheric texts, culture, concepts, and capital into the South American context, as seen in Las escuelas and the author's correspondence with Mary Mann. Exploring the relationship between the two reformers-both of whom were interested in using education to prepare nonwhites for the duties of citizenship in a broadly defined "South"-in order to examine the entangled history ${ }^{1}$ of Argentina during the War of the Triple Alliance and the early Reconstruction-era United States, I will show how Sarmiento puts Mann's interpretation of the North American myth of the self-made man and Reconstruction-era debates on suffrage and the freedmen to creative use in his effort to incorporate Argentina's popular classes into the national project through public education. I will reflect on the geopolitical implications of this entangled relationship, examining how it intervenes in the rise of the North American empire and the development of Argentina into a regional power during the War of the Triple Alliance. I argue that, while Sarmiento seeks to incorporate certain aspects of US culture into Argentine national life, his stance is one of critical adaptation rather than servile imitation. In this way, drawing on the fields of translation studies and twentieth-century Latin American cultural theory, I follow in the tradition that views Sarmiento as a creative transculturator ${ }^{2}-$ not a mindless

1. The aim of entangled histories is to discover the points of dynamic contact between national units that have traditionally been viewed as discrete, such as, in the case of this article, the Reconstruction-era United States and liberal Argentina during the War of the Triple Alliance. For detailed information on the concept of "entangled histories," see Jorge Cañizares-Esguerra; Jürgen Kocka; Shalini Randeria; and Michael Werner and Bénédict Zimmerman.

2. I am referring to Cuban anthropologist Fernando Ortiz's notion of transculturation as a way to describe dynamic social, cultural, and economic exchanges between colony and metropole and not Uruguayan theorist Ángel Rama's discussion of narrative transculturation in the literary relationship between periphery and semiperiphery in twentieth-century Latin American literature. 
recycler-of metropolitan ideas, and thus I contribute to recent scholarship that seeks to identify the Argentine statesman's influence on the metropolitan United States.

\section{Translation and Importation}

A consideration of Sarmiento's translation in terms of importation from the center to the periphery draws attention to the unequal political and economic realities underlying the writers' textual entanglements. ${ }^{3}$ As Silvia Spitta points out, "the transfer or translation" of elements from one cultural system to another "is seldom only intralingual," as "the transfer of languages, meanings, and literary traditions takes place . . . between two countries, one of which is in a relation of power and domination over the other" (15). Thus, when considered on an extraliterary scale, Sarmiento's translation of Mann becomes a textual embodiment of what Mary Louise Pratt calls the "contact zone," or "social spaces where disparate cultures meet, clash, and grapple with each other, often in highly asymmetrical relations of domination and subordination" (4). ${ }^{4}$ Through a series of transcultural transfers and discursive displacements, Sarmiento's Vida de Horacio Mann and the Escuelas volume in which it appears construct a specifically textual contact zone in which the developing and neocolonial Argentine Republic negotiates its identity

3. Lawrence Venuti argues for the value of what he calls "foreignizing translations," in which the source text introduces new ideas into the target language at the same time that translation into the target language yields a richer understanding of the source text. While Sarmiento does not concern himself with linguistic renovation, his textual entanglement with Mann does involve cultural importation, as the Argentine statesman uses his translation to import the tenets of North American bourgeois modernity — such as the myth of the self-made man and the notion of civilization through education-into his country's public sphere.

4. In the same vein, theorist Emily Apter considers translation to be a war zone, or "a broad intellectual topography that is neither the property of a single nation, nor an amorphous condition associated with postnationalism, but rather a zone of critical engagement that connects the 'l' and the 'n' of transLation and transNation." Though her emphasis is on "small nations or minority language communities," Apter's conceptualization of translation as a "zone," like Pratt's, is useful in understanding the sort of transnational literary and political engagements that I describe in this paper. Importantly, though Apter's "trans" metaphorically "operates as a connecting port," it represents "the point of debarkation to a cultural caesura-a trans-ation-where transmission failure is marked" (5), meaning that the translation zone is a point of both connection and disconnection. 
with and through the ascending North American empire of the postbellum period. ${ }^{5}$

That said, the extent to which Sarmiento's Vida de Horacio Mann "counts" as a translation of Mann's Life of Horace Mann is questionable, as the source text is 602 pages while the "translation" is a mere 57 and contains information not included in the English-language version. Sarmiento makes no effort to disguise his interventions into Mann's text, allowing his intercalations to stand freely, while placing the parts of his work that he has translated and transposed from the English-language version in quotes, though he does not use ellipses nor any other marker to signal the lengthy excisions from the translated passages that appear between the quotation marks. This strategy in some ways parallels the one employed by Mary Mann in the source text, in which she occasionally infuses her own narration into what is otherwise a string of Horace's journal entries and private correspondence that she has compiled and published. Yet, while this technique makes sense for a biographer-as biography presupposes two subjectivities, that of the author and that of the biographical subject-it does not for a translator, whose task, according to Lawrence Venuti, traditionally consists of serving as an "invisible" medium for transmitting the words written by the author of the source text, not as a speaker in his or her own right. Thus, "a translator does not quote, for a quotation supposes a relation of non-identity between the quoted text and the quoting context, and this is the distinction that a translator strives to erase" (Pérez Firmat 42). Therefore, while Sarmiento's system of quote-bounded translations and free-standing commentary reflects the visual and bibliographic effects of Mann's annotated compilation, it also, like a mirror, represents an inversion of that strategy. The title page of her book reads Life of Horace Mann, "by his wife"-even though Horace's words represent a greater percentage of the volume than do Mary's. In Vida de Horacio Mann, on the other hand, the "translator's" commentary—not Mann's text rendered into Spanish-actually occupies most of the pages. Such is the

5. Though transculturation is typically associated with twentieth-century efforts to vindicate New World subaltern cultures against the colonialist gaze of the metropole and the creole elites, I am arguing that Sarmiento, in his neocolonial project of disciplining the Argentine masses according to the norms of Western bourgeois civilization, adopts and adapts North American cultural constructs to the exigencies of Argentina's peripheral geopolitical location, altering the nature of those constructs as he does so. For another view on transculturation and neocolonialism, see Idelber Avelar, "Transculturation and Nationhood." 
extent of Sarmiento's changes to the source text that at one point he nonchalantly points out that Mary has published "algunos fragmentos" of Horace's diary without noting that they appear in the very work that he is supposedly translating (88).

Importantly, though the Argentine letrado does not refer to his work specifically as a translation, the Vida de Horacio Mann does appear a few pages after a letter from Sarmiento to Mary Mann in which he writes that he has "el pensamiento de acometer la traducción" of the Life of Horace Mann "al español," "adaptándolo a las ideas y las necesidades de la América del Sud."” On the one hand, the statement suggests that, despite the liberties he takes with the source text, Sarmiento intended the Vida to be read as a translation of the English-language work. On the other, in asserting that the act of translation will involve an adaptation of the North American text to the local exigencies of South America, Sarmiento acknowledges that the Vida de Horacio Mann is what Gustavo Pérez Firmat would call a "poor correspondent" of the Life of Horace Mann. The Argentine writer creatively mislabels as a "translation"-or, a simple transferal of syntagms across linguistic borders-a project that in fact represents a critical rewriting of the source material. This paradoxical nature of the text-simultaneously a translation and yet not-provides a framework not only for reading the Vida, but for understanding the broader sociopolitical project undertaken by Sarmiento in his Escuelas.

\section{Horacio criollo}

Building on Adriana Rodríguez Pérsico's claims in Un huracán llamado progreso that Sarmiento's ability, as reflected in his cosmopolitan reading practices, to interpret and synthesize a wide range of foreign sources constitutes the locus of his subjectivity (50-51), I argue that the writer, in his translational practice, adopts a contestatory stance towards Argentina's colonial legacy by situating himself within the peripheral zone of North-South entanglements in order to productively critique both Argentine and metropolitan cultures in a bilingual variation on the postcolonial counterdiscursive writing practices that Pérez Firmat dubs "critical criollism" (9). The Argentine

6. I have modernized and standardized Sarmiento's spelling here and throughout. 
author and statesman's "nordomanía" (to use modernista José Enrique Rodó's disparaging term for the excessive imitation of US and northern European culture) does not involve "docile emulation of foreign usage," but, rather, "a self-conscious, selective, and sometimes even willful manipulation" (Pérez Firmat 9) through a "dialectic of originality and derivativeness" (20). In his translational practice, Sarmiento seeks to modernize his country's cultural, political, and economic spheres by importing elements of North American national life into the Argentine cultural polysystem—goals that he sets forth in texts such as Las escuelas and Viajes (1850). Yet even as he turns towards the United States in order to cancel out the legacy that Spain, "esa rezagada a la Europa," bequeathed her colonies, Sarmiento remains fully aware of the cultural and geopolitical dangers of uncritical adoption of the North American model (10). Through his dialogue with Mann, Sarmiento attempts to recombine native and foreign elements in order to build and strengthen the Argentine nation-state so that the country may function as a protagonist—and not a pawn—of international affairs.

This critical cosmopolitanism was typical of Sarmiento and of the antiRosas liberal reformers of the Argentine Generación de 1837, whose openness towards Europe did not represent a full assimilation into Northern Hemispheric culture, but rather, a productive dialogue between domestic and foreign elements. Speaking of the group's frequent employment of Gallicisms in Spanish, Carlos Altamirano and Beatriz Sarlo write that "the Generation of 1837 claimed . . . for the first time in the history of Argentine culture, the right to contaminate Spanish in order to make it Argentine through the use of other European languages" (161). Looking abroad in order to forge a national subjectivity, the members of the Generación de 1837, in their "contamination," or foreignizing linguistic practice, represent an affront not only to the "xenophobic" Rosas and federalista politicians, but to the nativist discourse of casticismo, or cultural and linguistic purity, that, at the time, was in vogue in Spain, the former colonial metropole which the members of the Generation regarded as culturally retrograde (161). More than anything else, the Generation's move towards Europe represents a critical creolist move away from Spain.

The anecdote famously included in Sarmiento's "Advertencia del autor" in the first edition of Facundo, in which the writer, fleeing to Chile in order to escape Rosas's mazorca henchmen, writes the French quote "on ne tue point les idées" on the wall of a cave, much to the consternation of his monolingual pursuers, is often cited as an example of this instrumental and 
expropriatory relationship with foreign cultures. ${ }^{7}$ Sarmiento incorrectly attributes the quote to Fortoul, though it seems to be his own invention, or perhaps an adaptation or misrecollection of Diderot's "on ne tue pas de coups de fusils aux idées," which the Argentine letrado may have read in the Revue Encyclopédique (Jitrik 4). Some, such as Miriam Gárate, have pointed to this "quotation," which provides an unstable point of origin for Sarmiento's slippery foundational text, as an example of the author's "borrowed culture," or, in Ricardo Piglia's words, "cultura ostentatoria y de segunda mano" (17). ${ }^{8}$ However, such a reading is ungenerous. Far from reducing himself to the sort of "cultural vassalage" of which Venezuelan thinker Arturo Uslar Pietri accuses nineteenth-century Latin American letrados, Sarmiento "adopts" the seemingly misplaced quote to the Argentine context-a foreshock to what he would later do with the figure of Horace/io Mann. Though a fluent reader of French, on the title page of the 1845 edition of Facundo, Sarmiento deliberately mistranslates the quote as "a los ombres [sic] se deguella [sic]: a las ideas no." Not only does this "translation," in its departures from the source text, display an irreverent attitude towards the French Enlightenment, it subverts the rules of Academy Spanish by misspelling "hombres" and "degüella." Thus, as Piglia suggests in his canonical "Notas sobre el Facundo," Sarmiento's misquotation filters Northern Hemispheric lettered culture through the material realities of peripheral Argentina (a hasty exile from a regime that really does behead its opponents, leaving little time to corroborate sources or consider "fidelity" in translation, much less worry about the silent letters and diacritical markings that consternate the provincial author's self-education (15-17). Through his deliberate Argentinization of the misquoted text, Sarmiento "no solo ocupa, sino que maneja, un lugar subalterno respecto a la biblioteca europea" (Ramos 70)—and also, as I will show below, to North American cultural, political, and economic capital. The critical creolization involved in "managing" such a space works to fortify the Argentine national project, utilizing dialogue with foreign thinkers as an instrument to find solutions to the specific challenges his country faces in implementing republican ideas that would take Northern innovations into account while still fitting local conditions.

7. For a slightly different account of these events, see Guillermo Kuchen's interview with historian Edgardo Mendoza in Enrique Eskenazi's documentary Los viajes de Sarmiento.

8. For a classic critique of Sarmiento's cultural and political cosmopolitanism, see Ezequiel Martínez Estrada's Radiografía de la pampa (1933). 
This critical creolist desire to "adapt" Northern Hemispheric ideas to "the needs of South America" through transnational dialogue is evident in the title of Sarmiento's translation, Vida de Horacio Mann, which Hispanizes the subject's first name, thereby engendering an Argentine Horace/io Mann to renovate the South American cultural polysystem. ${ }^{9}$ Additionally, the change from "life" to "vida," though an obvious and literal glossing, causes the title of Sarmiento's work to resonate with the Roman Catholic hagiographic tradition of the vita, or saint's life. In this way, the Spanish-language text engages with a tradition far removed from the reconsideration of the New England Calvinist heritage with which much of the English-language version is concerned. ${ }^{10}$ In fact, in his initial letter to Mary on July 8, 1865 , Sarmiento goes so far as to tell her (in English) that "the name of Mr. Mann was for me, during all of my work and struggles for education, what the works of St. Augustine were for the missionaries of the church," in this way creolizing Horace Mann into a kind of secular saint (Ard 61).

Sarmiento clearly had an understanding of the generic tensions between religious hagiography and secular biography. In Recuerdos de provincia (1850), he claims to have commissioned a Spanish translation of Mignet's scholastic biography of North American Benjamin Franklin because he knows "por experiencia propia cuánto bien hace a los niños esta lectura" (243). He then proceeds to decry the absence of the biographical genre in early-nineteenth-century Hispanic letters:

¡Santas aspiraciones del alma juvenil a lo bello y perfecto! ¿Dónde está entre nuestros libros el tipo, el modelo práctico, hacedero, posible, que puede guiarlas y trazarlas un camino? Los predicadores nos proponen los

9. The fact that the Hispanization of historical figures' first names was a widespread practice in the nineteenth century- "Jorge Washington" is one of the more common examples—rather than lessening the significance of Sarmiento's title change, suggests the deep relationship between translation and transculturation during the early republican period.

10. Curiously, the passages criticizing New England Calvinism are omitted from Sarmiento's translation, ostensibly because, as the Argentine writes in a September 12, 1866 letter to Mary Mann, "that Calvinist preacher is an exact copy of our Catholic preachers and I didn't want to create controversy" (Ard 227). Sarmiento's letters to Mann from before his assumption of the presidency have been collected and translated by Ard and appended to Seeds of Reform. Whenever possible, I will quote from the Academia Argentina de las Letras's somewhat incomplete Spanishlanguage edition of Sarmiento's letters to Mann, from which the September 12th, 1866 letter is, unfortunately, missing. 
santos del cielo para que imitemos sus virtudes ascéticas y sus maceraciones; pero por más bien intencionado que el niño sea, renuncia desde temprano a la pretención de hacer milagros, por la razón sencilla de que los que lo aconsejan, se abstienen ellos mismos de hacerlos. (243)

Rather than the fantastic lives of saints, Sarmiento feels that the young would profit more from reading about self-made men such as Benjamin Franklin:

El joven que sin otro apoyo que su razón, pobre y destituido, trabaja con sus manos para vivir, estudia bajo su propia dirección, se da cuenta de sus acciones para ser más perfecto, ilustra su nombre, sirve a su patria, ayudándola a desligarse de sus opresores, y un día presenta a la humanidad entera un instrumento sencillo para someter los rayos del cielo, y puede vanagloriarse de redimir millones de vidas con el preservativo con que dotó a los hombres, este hombre debe estar en los altares de la humanidad, ser mejor que Santa Bárbara, aboga contra rayos, y llamarse Santo del Pueblo. (243)

In this critical creolist notion of the "Santo del Pueblo," Sarmiento replaces St. Barbara, patroness of storms, with Benjamin Franklin, inventor of the lightning rod, suggesting a teleology in which destructive natural forces are subjugated by manmade technology and innovation triumphs over tradition.

The Vida de Horacio Mann displays the same bourgeois-modern outlook found in the above quote, adopting the hagiographic form in order to empty the genre of its religious content and replace it with liberal-democratic reform in accordance with Sarmiento's sociopolitical program for Argentina. Rather than reinscribe the official Catholic traditionalism of the Rosas regime through the vita, Sarmiento turns the genre against itself, replacing education for religious piety with education for the republican polity through the story of upward mobility through self-improvement that the text relates. In this way, Sarmiento entangles the colonial Hispano-Catholic technology of the hagiography with the foreign genre of the secular biography in order to construct a space for the modern myth of the self-made man in Argentine public life and, in this way, import the particular form of bourgeois modernity that that myth represents into the Argentine cultural sphere. ${ }^{11}$

\footnotetext{
11. Thus, if Sarmiento's writings on the lives of Quiroga, Aldao, and el Chaco are, as Rodríguez Pérsico argues, "biografías de la barbarie" that serve to turn the semantic tables on the hegemonic federalistas by scripting them as outside the national project, his Vida de Horacio Mann represents an effort to incorporate civilizing elements into that same project (98-117). At the same time, however, the work changes the traditional focus of the biographical genre in Argentine letters,
} 


\section{Entangled Education}

Translation and education represent two intertwined elements at the heart of Sarmiento's nation-building project. In addition to penning the Vida de Horacio Mann, Sarmiento founded the journal Ambas Américas, which translated North American articles on education into Spanish. Meanwhile, the Mignet scholastic biography of Franklin that Sarmiento had translated, as well as the Vida de Lincoln that he commissioned, furthered his efforts to import the myth of the self-made man into the Argentine cultural polysystem. Sarmiento's translations contribute to Argentine public life by looking abroad for models of how the nation can emerge out of barbarism and into civilization by following the path of education-models that the statesman feels are lacking in an Argentina still struggling to overcome the cultural legacy of Spanish colonialism.

For Sarmiento, public education is the way to produce ideal citizens for the nation-state. He feels that the democratic revolutions of the nineteenth century have caused political theory to advance more rapidly than human science, granting rights to the people before the people are necessarily prepared to exercise them. In De la educación popular (1849), he writes that the adoption of political equality as "la base de organización social" following the democratic revolutions of the nineteenth century creates "la obligación de todo gobierno a proveer de educación a las generaciones venideras, ya que no puede compeler a todos los individuos de la presente a recibir la preparación intelectual que supone el ejercicio de los derechos que le están atribuidos" (18-20). Writing at a moment marked by hegemonic antiintellectualism on the part of the Federalist government and difficult access to education for the popular classes, he warns, "no educando a las generaciones nuevas, todos los defectos de que nuestra organización actual adolece continuarán existiendo" (26).

These attitudes are reflected in Sarmiento's January 29, 1866 letter to Mary

which from Sarmiento's Facundo to Bartolomé Mitre's Historia de Belgrano (1857) to Juan Bautista Alberdi's contestatory Grandes y pequeños hombres del Plata (1867) had used life stories as points of departure for national histories. Vida de Horacio Mann, on the other hand, is not as concerned with the history of Argentina as with what that country can learn from the history of the United States, as reflected in the life of Horace Mann. While the Vida persists in using the "great man" as a metonymy of the nation, it refers to a different nation, not as an explanation of the present, but as a model for the future. 
Mann. In language that may make twenty-first century readers uncomfortable, the Argentine minister comments that, "por distracción hago el borrador de un discurso, que podría pronunciar en la Convención de Superindententes, sobre la admisibilidad de las gentes de color a la ciuda[da]nía, con la calificación para blancos y negros de saber escribir, como prueba de que poseen por lo menos leyendo, los medios de unir su existencia, ideas y juicios a la tradición humana." Echoing ideas expressed in his Educación popular, he argues that such knowledge "funda la libertad," which is "un sentimiento, pero que necesita para asegurarla, el conocimiento de todos los mecanismos que la experiencia ha subministrado durante siglos" (Cartas 98).

While Mann voices disagreement with these views in her February 20, 1866 response, arguing that Southern prejudice would lead to the unfair application of any literacy requirement and that "the blacks are really better \& more intelligent than the poor whites of the South, \& better capable to vote" (Velleman 77), she shares Sarmiento's concern for the education of the freedmen. In an October 15, 1865 letter to Sarmiento, she comments favorably on the practice of sending upper-class New England women to the South to teach the newly emancipated slaves (Velleman 55-56).

A tireless reformer, Mary soon began collaborating with Sarmiento to send those same New England schoolteachers even further South-to Argentina. ${ }^{12}$ As in Juanita (1887), a posthumous novel in which Mann conflates the US South with Cuba in order to express antislavery sentiments, here, too, she collapses the two Souths into each other in her efforts to further the cause of New England-style education. In a September 6, 1866 letter, she even speaks to Sarmiento of a couple that is going to Florida to teach the freedmen and says she will try to convince them to go to Argentina (Velleman 101). In this imaginary, the Panhandle and the pampas represent interchangeable parts of the same hemispheric educational factory system, two faces of a decadent, feudal extended "South" defined against the enlightened "North" of New England. ${ }^{13}$

Much as, according to Julio Ramos, Sarmiento's orientalism "proyecta,

\footnotetext{
12. For more on the North American school teachers sent to Argentina, see Luigi.

13. On the extended South, see Carolina F. Levander and Robert S. Levine, "Introduction: Hemispheric American Literary History." For more examples of Mann's projection of the US South and the North American Civil War onto the struggle between unitarios and federales in Argentina, see her Life in the Argentine Republic in the Days of Tyrants.
} 
por parte de quien no es europeo, un deseo de inscribirse en el interior de la cultura occidental," as it "implica un lugar de enunciación-ficticio-fuera de la 'barbarie' (lo no europeo), enfáticamente 'civilizado' " (69; emphasis in the original), here, too, the Argentine statesman tries to position himself as a Northern liberal in the North/"South" schema outlined above. He displays a particular interest in the education of the freedmen, including a chapter on the "Educación de los negros libertos" (207-16) and reprinting a speech by a "Profesor Greene de Rhode Island" to the "Asociación Nacional de Maestros" on the subject (171-72) in his Escuelas. At another point, he suggests that Missouri's slow development is due to the presence of slaves in the state, an opinion that he juxtaposes with a discussion of illiteracy in the US South, which, he claims, is even "más negro . . que la negra servidumbre" (28), thereby tying slavery and lack of education together in the same package of reformist ideas.

Like Mann, Sarmiento sees the former Confederate States of America and Argentina as part of one large, backward extended South waiting to be civilized by Yankee know-how. In Las escuelas, he applauds Northern efforts to educate the freedmen while commenting offhandedly that "los hombres de color de los Estados Unidos no se encuentran más faltos de educación que los habitantes blancos de nuestras campañas" (11). As the US South and Argentina are equivalent, it stands to Sarmiento's reason that the solutions applied in one region should work well in the other. At another point in the book, he says that he is including excerpts from the Freedman and notes that "muy tristes reflecciones sobre sí mismos traerá su lectura a los americanos del Sur." ${ }^{14}$ He continues by commenting that "esta será el primer movimiento: el segundo ha de ser, lo esperamos, seguir tan noble ejemplo" (216). For Sarmiento, as for Mann, Argentina is a variation on the US South, and would do well to follow its Northern Hemispheric counterpart's path on the road to civilization. Thus, much as Sarmiento recasts the life of Horace Mann into an Argentine Catholic context, so, too, does he "translate" the Confederacy as Argentina and US freedmen as Argentine masses in his effort to achieve political stability in the country through public education. ${ }^{15}$

\footnotetext{
14. Sarmiento would provide these reflections in the "Blancos y negros" chapter of Ambas Américas (vol. 2, 60-61).

15. Students of Argentine history, accustomed to thinking of the project to import North American schoolteachers-which lasted from 1869 to 1916 (Luigi 17) - in the context of urban immigration, may find these comparisons with the rural US South unnatural. However, Sarmiento first
} 


\section{From Translation to Foreign Policy}

As Piglia notes, for Sarmiento, "conocer es comparar. Todo adquiere sentido si es posible reconstruir las analogías entre lo que se quiere explicar y otra cosa que ya está juzgada y escrita" (17). The entanglement between cultures indicated by this search for analogies between the Reconstruction-era US and Rosas's Argentina served Sarmiento's modernizing goals well, opening the door for New England schoolteachers to travel to the deeper South and reconstruct the Argentine masses into productive citizens in an effort parallel to the one underway in the former Confederate States of America at the same moment. ${ }^{16}$ Yet, despite the desire to form an "Estados Unidos de la América del Sur" (16) analogous to the one in the North that the author famously proclaims in Argirópolis (1850), it unfair to claim that Sarmiento chose to obviate the differences between Argentina and the United States, as adherents of the "borrowed culture" school would suggest. This is made manifest in his Viajes-a book often cited (correctly) as the example par excellence of Sarmiento's nordomanía-in the author's constant references to his difficulties in communicating with Americans. Playing ironically on his lessthan-native command of the English language, Sarmiento, in his Spanishlanguage narrative, describes what he sees in the US as "impresivo" (instead of the more linguistically appropriate "impresionante")—drawing attention to the Anglicism by setting it in italics (221)—much as he would later winkingly rename Horace Mann "Horacio" in his Vida. Hispanizing the English term in a self-conscious fashion, he points to the productive difference between cultures. In much the same way that Sarmiento's lack of fluency in

thought of his plan upon reading "un artículo aparecido en enero de 1866 en el Harper's Weekly, en el que se describía el éxodo de 600 maestras de escuela yanquis hacia el territorio de Oregón” (Luigi 38). The project, then, was inspired by similar efforts to "civilize" the North American West-a region that Sarmiento repeatedly compares to rural Argentina in Facundo and Viajes. It thus seems that while the US teachers ultimately worked more with the urban immigrant masses than with the rural popular classes, the Argentine countryside was, at the very least, on Sarmiento's mind at the moment of the project's inception.

16. Sarmiento's reading of Rosas-era Argentina onto the United States during Reconstruction was not an isolated incident in the nineteenth-century New World lettered sphere. Not only does the comparison between the struggles between the Union and the Confederacy in the United States and the unitarios and the federales in Argentina return in Mary Mann's preface to her translation of Facundo, it appears in Juan Bautista Alberdi's Grandes y pequeños hombres del Plata, published in the same year as Sarmiento's Escuelas. Meanwhile, as late as 1965, North American historian Donald E. Worchester claims that the South American conflict was "in many ways a counterpart of our own Civil War” (v). 
English produces creative variations on the language when he translates it back into Spanish, Argentina is not the "Estados Unidos del Sur," but-as the writer says in his initial letter to Mann-can "adapt" certain Northern themes to the South American context.

This creative "management" of his "subaltern place" (to reiterate Ramos's terms) that Sarmiento's playful insistence on his seeming inability to speak with Americans suggests opens a space for mild critique of the North American republic's burgeoning modernity. Amidst the exuberant praise for the United States that he expresses in his Viajes, Sarmiento finds room to manifest concern regarding the Lynch Law (147), question the literal interpretation of the Bible practiced by some Protestant groups (148), and wonder whether Americans have allowed what the Argentine writer sees as ignorant immigrant masses to exert too much influence in their elections (266-267). The author's harshest critiques, however, are reserved for slavery, which he condemns repeatedly throughout his book before declaring, "echámosle en cara a los norteamericanos su perpetuación" (276) — direct language rendered all the stronger by the statement's location in the final pages of Sarmiento's travel narrative.

The writer's comments on US expansionism are particularly illustrative of his stance towards the North American metropole:

Yo no quiero hacer cómplice a la Providencia de todas las usurpaciones norteamericanas, ni de su mal ejemplo que en un periodo más o menos remoto puede atraerle, unirle políticamente o anexarle como ellos llaman, el Canadá, Méjico, etc. Entonces, la Unión de los hombres libres principiará en el Polo del Norte, para venir a terminar por falta de tierra en el Istmo de Panamá. (Viajes 470)

In this quote, Sarmiento appears to condemn American "usurpations" of Mexican territory in his effort to distance them-at least rhetorically-from acts of "Providence" at the same time that he, paradoxically, looks forward to an American-led hemispheric union of the free. Thus, rather than "borrow" from Northern books, Sarmiento, as Diane Sorensen Goodrich argues, "appropriates hegemonic culture whilst maintaining a critical eye and demanding that the metropolitan powers transmit knowledge in ways that do not maintain colonialism" ("Postcolonial Liminality" 110). Though the views of North American modernity expressed in Viajes are almost overwhelmingly 
laudatory, the examples mentioned here demonstrate that that praise is not unqualified. The future Argentine president seeks to learn from the United States, not reproduce its occasional errors, much less submit to the rising Northern hegemon.

A critical creolist, Sarmiento was anxious to find a way of putting North American cultural capital to the service of his own political goals-an interest that he was, perhaps, more reticent to express in his texts intended for publication than he was in his personal letters to Mann, in which he repeatedly speaks of the need to inform North Americans about Latin American politics and society in light of the United States's incursions across its southern borders. In a September 28, 1865 letter to Mann, for example, he comments that he wants to publish a "historia de las escuelas de la América del Sud" in English in order to "llamar la atención de los norteamericanos, a aquellos países, interesarlos en su suerte." In a thinly veiled allusion to the imperialist Mexican War, Sarmiento writes, "cambiadas ya las malas tendencias de la política esclavocrata, de anexación y de conquista," he wants to "señalar a la filantropía americana el camino de extender la República, que es la educación común" (Cartas 211).

A November 25, 1865 letter to Mann is more direct. Sarmiento lists the political problems of Latin America, including civil wars and the French invasion of Mexico, and complains that "cuando nos ven envueltos en el polvo de tanto desquicio no solo nos abandonan, sino que nos menosprecian" (Cartas 196). While he defends the Monroe Doctrine in Las escuelas, arguing that the US is the natural protector of Spanish America (297-98), he also condemns imperialism in general, and North American expansionism in particular (299-300). All of this suggests that Sarmiento, who has dedicated so much of his life to learning about and disseminating North American cultural and political institutions in Argentina through didactic translations, realizes that the equation is one-sided, that most North Americans do not reciprocate his interest in inter-American understanding. Moreover, as his comments on Mexico show, he is aware of the catastrophic consequences that that intellectual trade imbalance can cause. Thus, even as Sarmiento seeks to adopt many North American cultural institutions-as his creolization of the self-made Horace/io Mann and his plans to import New England schoolteachers demonstrate-true to form, he mobilizes education as a means to stave off full absorption by the elements of North American modernity that he finds less than civilized. Once again, the writer's relationship with the United States 
proves instrumental, a means of buttressing and protecting his plans for the Argentine nation-state. ${ }^{17}$

Sarmiento is unwilling to allow Argentina, along with Uruguay and Brazil, its allies in the War of the Triple Alliance against Paraguay (also called the Paraguayan War in English), ${ }^{18}$ to meet the same fate of North American indifference as Mexico under Maximilian has. On October 12, 1866, he informs Mann (in English) that he is "writing some explanations on the motives and object of the Paraguayan war, in order to counteract the mischievous influence the names Empire and Republic, as Brazil and Paraguay are regarded, have on public opinion" in the US (Ard 235). Meanwhile, on January 3, 1867, Sarmiento complains "Los diarios hallan útil, sensational estar a favor de aquellos salvajes. Es en vano mostrarles la verdad. La verdad es una desgracia para ellos. Es preciso que la raza guaraní se sobreponga a la europea, que el tirano creado por los jesuitas nos domine a nosotros que trabajamos por ser civilizados" (Cartas 21). Typically, he describes Paraguay as a land immersed in indigenous atavism and casts the War of the Triple Alliance as a struggle between civilization and barbarism. He attempts to enlist Mann's help in spreading what he sees as the truth about Paraguayan barbarism among the North American public_-which, the Civil War still a fresh memory, favored republican Paraguay over imperial Brazil, much to the Argentine president's chagrin — by asking her to translate an article he had written on the subject (257).

The result of Sarmiento's request appears to be Revelations on the Paraguayan War and the Alliances of the Atlantic and the Pacific, ${ }^{19}$ which continues

17. For a different reading of Sarmiento's thoughts on the Mexican-American War, see David Viñas 6-22.

18. Succinctly, Paraguay and Uruguay had been federalista strongholds. In April of 1863 , there was a unitario coup in Uruguay. Brazil came to the aide of the unitarios, while Argentina under President Mitre secretly provided Brazil with arms. In retaliation, President Solano López of Paraguay began a war with Brazil and Argentina (Katra 255-59).

19. Recently digitized by the Biblioteca Nacional de Argentina and included on the Proyecto Sarmiento website, the rare text was published by Hallet \& Breen in New York in 1866 "sin mención de autor," though the Biblioteca Nacional refers to it as "perteneciente a Sarmiento," adding only that "no hay tampoco referencia al traductor," although "suponemos que se trata de Mary Mann" (2). The letter quoted above, in which Sarmiento asks Mann to translate his article on the Paraguayan War, and the stylistic similarities between the Revelations and Mann's signed translation of Facundo lend credence to the Biblioteca Nacional's assertions as to the text's origins. Moreover, Sarmiento is identified as the author of the Revelations in an article in the September 1867 edition of The Radical signed by "E.P.P." — clearly Elizabeth Palmer Peabody, a known contributor to the transcendentalist magazine. Mary Mann's sister and Sarmiento's acquaintance, Elizabeth Peabody would have been in a position to know about the clandestine translation. 
the South/South mirroring found in Las escuelas, but-however improbably-substitutes the Argentine civil strife of the first half of the nineteenth century with the War of the Triple Alliance as a parallel to the US Civil War, which the text explains as a war to preserve civil society. For example, the (historically problematic) term "serf" is used to describe the Paraguayans throughout the pamphlet, which repeatedly attributes the country's success in the war to the fact that its people have no choice but to do their dictator's bidding - an observation that sounds suspiciously like many a description of antebellum slavery in the US. In the same vein, much as Sarmiento sees the Southern US poor whites reflected in the Argentine masses, Mann sees the "barbaric" Paraguayan government as another iteration of the Confederacy, to which she compares it in a November 9, 1866 letter (Velleman 108). She even goes so far as to say in the Biographical Sketch that she includes in her translation of Facundo that the Paraguayan people have been "enslaved" by the dictator López, this time collapsing not only the Southern Cone into the US South, but Afro-North American chattel slaves into the mostly indigenous population of Paraguay.

The entanglement described here cannot be dismissed as harmless literary figuration, especially because Mann does not publicly acknowledge her (or Sarmiento's) role in the production of the Revelations and because her comments in Life in the Argentine Republic are delivered from her relatively authoritative position as translator. Mann is (perhaps too) interested in helping Sarmiento disseminate pro-Argentine information among the North American public. In a letter to Sarmiento that Velleman tentatively dates April 18, 1869, she writes:

Mr. Garcia wrote me a short time since that he wished I would prepare an article for some public paper or journal upon the subject of Lopez and promised me more information. I am all ready to do my best, but he gave me so impressive a warning not to speak of Gen Mac Mahon [sic] that I withdrew one article I had prepared for the Advertiser just as Mr. Dunbar the Editor was going to put it to press. The young man who wrote the article that troubles you so much is no longer in the office. Mr. Dunbar was in Europe at the time. Whenever you wish me to put any thing into the Advertiser if you will say so in so many words, I will have it put in as a direct quotation from a letter from you - or if you prefer it, [I] will say «from an authentic source», and then shape it in my own words. I am 
afraid of doing mischief and giving you trouble by venturing to judge for myself upon so important a matter. (255)

This letter speaks to the covert power underlying the translational entanglement of Mann and Sarmiento. In addition to the ominously intriguing reference to "the young man who wrote the article that troubles [Sarmiento] so much" who is, for reasons that Mann does not clarify, "no longer at the office," it should be noted that the Mr. García to whom Mann refershusband of Eduarda Mansilla de García, whose novel, Lucía Miranda, opposes the sort of bourgeois modernity that Sarmiento wished to implement in Argentina and whose Médico de San Luis (1860) Mann would translate into English-was the Argentine diplomat who succeeded Sarmiento in the United States and was, at the time, serving in France. His father-in-law had been on the Federal side during the conflicts described in Facundo and his brother-in-law, Lucio V. Mansilla, best friend of Sarmiento's son, Dominguito (who died in the war with Paraguay), would later write Una excursion a los indios ranqueles (1870), a critique of Sarmiento's anti-indigenous policy. In her letter, Mann offers to intercede by infiltrating the Boston press with any information that Sarmiento, now president of Argentina, would like to have released secretly. Despite Mann's disclaimer that she is "afraid of doing mischief," the implications of this letter, though not quite illegal, are thoroughly scandalous. The widow of a former senator, Mann is offering to provide clandestine aid to the president of a foreign country in an international conflict in which the United States is supposedly neutral. ${ }^{20}$ Her intervention here-largely motivated by the understanding of the War of the Triple Alliance as a variation on the US Civil War and of the Argentine and Paraguayan masses as austral iterations of white Southerners and freedmen at which Sarmiento has helped her to arrive- has the potential to further the Argentine president's modernizing project, which regards federalista Paraguay as a thorn in its side. At the same time, it represents a foreshock to the kind of neoimperialism that would characterize North American foreign policy in the hemisphere in the following generation, rendering Argentina in the War of the Triple Alliance a sort of dress rehearsal for what would happen in Cuba in 1898 and in Panama in 1903.

20. Indeed, on May 25, 1869, the Manuel García alluded to in the letter writes to inform Mann that he read her article on the Paraguayan War "with interest" before sending a copy to the Brazilian Minister (Cartas 316). 
Thus, in the end, the hemispheric textual entanglements that I have been describing in this article become more than a technique for importing foreign ideas into a culture. They are a bulwark of the emerging inter-American state system in which Mann and Sarmiento are shrewd and important players. ${ }^{21}$ In this way, Sarmiento's "translation" of North American cultural capital into the Argentine polysystem, rather than a mere imitation, participates in a critical dialogue that serves to further entangle the hemisphere's geopolitical order.

\section{Bibliography}

Alberdi, Juan Bautista. Grandes y pequeños hombres del Plata. 1879. Buenos Aires: Garnier Hermanos, 1912.

Altamirano, Carlos, and Beatriz Sarlo. "The Autodidact and the Learning Machine." In Halperín Donghi, et al. 19-30.

Apter, Emily. The Translation Zone: A New Comparative Literature. Princeton, NJ: Princeton UP, 2006.

Ard, Patricia M. "Seeds of Reform: The Letters of Mary Peabody Mann and Domingo Faustino Sarmiento." PhD dissertation, Rutgers University, 1996.

Avelar, Idelber. "Transculturation and Nationhood." In Latin American Literatures: A Comparative History of Cultural Formations (3 vols). Ed. Mario Valdés, Djelal Kadir, and Linda Hutcheon. New York: Oxford UP, 2004. University of Toronto. Web. 7 Jul. 2013.

Balderston, Daniel, ed. The Historical Novel in Latin America. Gaithersburg, MD: Hispanoamérica, 1986.

Brickhouse, Anna. Transamerican Literary Relations in the Nineteenth-Century Public Sphere. Cambridge, UK: Cambridge UP, 2004.

Cañizares-Esguerra, Jorge. "Entangled Histories: Borderland Historiographies in New Clothes?" The American Historical Review 112 (2007): 787-99. History Cooperative. Web. 30 Apr. 2012.

Gárate, Miriam V. Civilização e barbárie n'os Sertões: entre Domingo Faustino Sarmiento e Euclides da Cunha. São Paulo: Fapesp; Campinas, Braz.: Mercado de Letras, 2001.

Goodrich, Diane Sorensen. "Postcolonial Liminality: Sarmiento and Metropolitan Cultures." In Studies in Honor of Enrique Anderson Imbert. Ed. Nancy Abraham Hall and Lanín A. Gyurjo. Newark, DE: Juan de la Cuesta, 2003.

Halperín Donghi, Tulio, Iván Jaksić, Gwen Kirkpatrick, and Francine Masiello, eds. Sarmiento, Author of a Nation. Berkeley: U of California P, 1994.

Jitrik, Noé. "De la historia a la escritura: predominios, disimetrías, acuerdos en la novela histórica latinoamericana." In Balderston 13-29.

21. On the inter-American state system, see Anna Brickhouse, Transamerican Literary Relations in the Nineteenth-Century Public Sphere. 
Katra, William. The Argentine Generation of 1837: Echeverría, Alberdi, Sarmiento, Mitre. Madison: Associated University Presses, 1996.

Kocka, Jürgen. "Comparison and Beyond." History and Theory 42 (Feb. 2003): 39-44. Wesleyan University. Web. 30 Apr. 12.

Levander, Carolina F., and Robert S. Levine. "Introduction: Hemispheric American Literary History." American Literary History 18 (2006): 397-407.

Los viajes de Sarmiento. Dir. Enrique Eskenazi. Prod. Grupo Peterson. YouTube, 2012. Video.

Luigi, Alice Houston. Sesenta y cinco valientes: Sarmiento y las maestras norteamericanas. Trans. Raquel Ottplenghi. Buenos Aires: Ágora, 1959.

Mann, Mary. Juanita: A Romance of Real Life in Cuba Fifty Years Ago. 1887. Ed. Patricia M. Ard. Charlottesville: UP Virginia, 2000.

- Life in the Argentine Republic in the Days of Tyrants. 1868. New York: Hafner, 1960.

- Life of Horace Mann. Boston: Walker, Fuller, and Co, 1865.

Mansilla, Lucio V. Una excursión a los indios ranqueles. 1870. Ed. Saul Sosnowski. Miami: Stockero, 2007.

Mansilla de García, Eduarda. Lucía Miranda. 1860. Biblioteca Virtual Universal. 2003. Web. $1 / 7 / 11$.

—. El médico de San Luis. 186o. Ed. Rafael Pombo. Buenos Aires: Biblioteca Popular de Buenos Aires, 1879. Edu.mec. Web. 2/1/o2.

Martínez Estrada, Ezequiel. Radiografía de la pampa. Buenos Aires: Babel, 1933.

Ortiz, Fernando. Contrapunteo cubano del tabaco y de azúcar (advertencias de sus contrastes agrarios, económicos, históricos y sociales, su etnografía y su transculturación). 1940. Ed. Enrico Mario Santí. Madrid: Cátedra, 2002.

Peabody, Elizabeth Palmer. "Death of Captain Sarmiento and Lieutenant Paz." The Radical 3 (1867): 28-34. Web. Google Books. Oct. 2012.

Pérez Firmat, Gustavo. The Cuban Condition: Translation and Identity in Modern Cuban Literature. Cambridge, UK: Cambridge UP, 1989.

Piglia, Ricardo. "Notas sobre el Facundo." Punto de Vista 8 (1980): 15-18. Scribd. Web. 15 Jun. 2013.

Pratt, Mary Louise. Imperial Eyes: Travel Writing and Transculturation. London: Routledge, 1992.

Rama, Ángel. La ciudad letrada. Hanover, NH: Ediciones del Norte, 1984.

- La transculturación narrativa en América latina. Mexico City: Siglo XXI, 1982.

Ramos, Julio. Desencuentros de la modernidad en América Latina: literatura y política en el siglo XIX. 1989. Caracas: El Perro y la Rana, 2009.

Randeria, Shalini. "Entangled Histories of Uneven Modernities: Civil Society, Caste Solidarities and Legal Pluralism in Post-Colonial India." In Unraveling Ties: From Social Cohesion to New Practices of Connectedness. Ed. Yehuda Elkana, Ivan Krastev, Elisio Macamo, and Shalina Randeria. Frankfurt: Campus. 284-311.

Rodó, José Enrique. Ariel. 1900. Ed. Belén Castro. Madrid: Cátedra, 2004.

Rodríguez Pérsico, Adriana. Un huracán llamado progreso. San José: U de Costa Rica, 1993. 
Sarmiento, Domingo Faustino, ed. Ambas Américas: Revista de Educación, Bibliografía y Agricultura. 3 vols. New York: Hallet and Breen, 1867-1868. Proyecto Sarmiento. Web. 8 Jul. 2013.

- Argirópolis, o, la capital de los Estados Confederados del Río de la Plata. Santiago, Chile: Julio Belín, 1850. Proyecto Sarmiento. Web. 1 Jul. 2013.

- Cartas de Sarmiento a la señora Mary Mann. Buenos Aires: Academia Argentina de las Letras, 1936.

—. De la educación popular. Santiago, Chile: Julio Belín i Compañía, 1849. Google Books. Web. 25 Jul. 2011.

—. Facundo. 1845. Ed. Alberto Palcos. Buenos Aires: Ediciones Culturales Argentinas, 1961.

- Facundo: civilización y barbarie. 1845. Ed. Noé Jitrik. Barcelona: Ayacucho, 1995.

—. Las escuelas: base de la prosperidad i de la república en los Estados Unidos. 1867. New York: Appleton, 1870. Google Books. Web. 5 Oct. 2012.

- Recuerdos de provincia. 1850. Buenos Aires: Emecé, 1944.

- Revelations on the Paraguayan War and the Alliances of the Atlantic and the Pacific. Trans. Mary Mann. New York: Hallet \& Breen, 1866. Proyecto Sarmiento. Web. 2 May 2012.

- Viajes por Europa, África y América: 1845-1847. Obras de D. F. Sarmiento. Tomo V. 1847. Santiago, Chile: Gutenero, 1886. Biblioteca Virtual Miguel de Cervantes. Web. 4 Oct. 2010.

- Vida de Aldao. 1843. Proyecto Sarmiento. Web. 7/25/11. . Vida de Lincoln, décimo sesto presidente de los Estados Unidos. New York: Apple-
ton, 1866. Hathi Trust Digital Library. Web. 12 Dec. 2010.

Spitta, Silvia. Between Two Waters: Narratives of Transculturation in Latin America. Houston: Rice UP, 1995.

Uslar Pietri, Arturo. En busca del nuevo mundo. Mexico City: Fondo de Cultura Económica, 1969.

Velleman, Barry, ed. My Dear Sir: Mary Mann's Letters to Sarmiento, 1865-1881. Buenos Aires: ICANA, 2001.

Venuti, Lawrence. The Translator's Invisibility: A History of Translation. London: Routledge, 1995.

Viñas, David. Viajeros argentinos a Estados Unidos. Buenos Aires: Santiago Arcos, 2008.

Werner, Michael, and Bénédict Zimmerman. "Beyond Comparison: Histoire croisée and the Challenge of Reflexivity." History and Theory 45 (2006): 30-50. Wesleyan University. Web. 21 Apr. 2012.

Worchester, Donald E. Foreword. Independence or Death! The Story of the Paraguayan War. By Charles J. Kolinski. Gainesville: U of Florida P, 1965. 